Bangl. J. Vet. Med. (2007). 5 (1 \& 2): 71-76

\title{
STUDIES ON THE DISEASES AND MORTALITY PATTERN OF GOATS UNDER FARM CONDITIONS AND SOME FACTORS AFFECTING MORTALITY AND SURVIVAL RATES IN BLACK BENGAL KIDS
}

\author{
M. Ershaduzzaman, M. M. Rahman, B. K. Roy and S. A. Chowdhury \\ Goat and Sheep Production Research Division, Bangladesh Livestock Research Institute, Savar, Dhaka-1341, \\ Bangladesh
}

\begin{abstract}
The research work was carried out from July 2004 to June 2005 and the place of research work was Bangladesh Livestock Research Institute (BLRI). The objectives of this work were to investigate the diseases and mortality pattern of goats and some factors affecting mortality and survivability rates of Black Bengal goats under intensive and semi-intensive management, in permanent house. Goats were only vaccinated with Peste des Petits Ruminants (PPR), administered with anthelmintics and dipped in $0.5 \%$ Malathion or $0.02 \%$ Diazinon solution to control endo- and ecto-parasites, respectively. They were allowed to graze 6-7 hours along with supplemental concentrate and green forages whereas ad libitum green grasses and concentrate were supplied to the goats managed under intensive management. The diseases were recorded mainly on the basis of clinical symptoms shown by animals and some by laboratory diagnosis; mortality was confirmed by some laboratory tests and clinical findings before death if any. Adult goats $(>1 \mathrm{yr}$ of age) died mostly due to suspected enterotoxaemia in the dry season (October to March) when there were shortages of green grasses in the grazing lands, which were confirmed by Gram's staining and ELISA tests, and female goats died significantly more than male. Growing goats (312 months of age) mortality was about $22 \%$, died mostly due to diarrhoea and pneumonia and mortality was higher (nearly $40 \%)$ in hot and wet season (July to October). The overall kid (0-3 months of age) mortality within study period was about $29 \%$, of which the major causes were infectious (63\%) i.e., diarrhoea, pneumonia, ecthyma and enterotoxaemia. Excluding accidental causes (predators and mechanical) mortality was reduced to about $18 \%$.Kid mortality was affected by birth weight which was just opposite to mortality. It was also affected by birth seasons, litter size, sex of kids, dam's body weight at kidding but parity was no significant effect on kid mortality Kids like growing goats, also died significantly more during hot and wet season. Morbidity was higher in female goats where mostly diarrhoea and pneumonia and some sorts affected all age groups of goats by ecthyma. There were seasonal differences.
\end{abstract}

Key words: Black Bengal, diseases, goats, kids, mortality

\section{INTRODUCTION}

Small ruminants especially goat is very important in rural economy and nutrition and has the potentially of using it as a tool for poverty reduction in Bangladesh. Goats, as far as known, were probably the first domesticated animals (Herre and Rohrs, 1973).At present, there are 677 million goats and represents fourth largest livestock group of the world (Morand-Fehr and Boyazoglu, 1999). Most of the goats (90\%) reared are Black Bengal (Amin et al., 2001), reputed for their prolificacy, fertility, early sexual maturity, adaptability to hot humid conditions and superior quality meat and skin (Devendra and Burns, 1983; Hussain, 1999; Amin et al., 2001). Relatively low birth weight, slow growth rate and insufficient milk produced by does, were identified as the major constraints directly associated with higher kid mortality and this is responsible for reduction of the total productivity (Husain, 1993). Season of birth, type of birth, birth weight and parity- all have significant effect on kid mortality (Acharya, 1988). Medium and large farmers interested in commercial goat farming are managed either in intensive or semi-intensive conditions. This system of goat rearing inherently incurs different diseases which intern reduces profitability of farming by treatment costs, reducing productivity and by mortality. Till now no systematic observation has been made on incidence of different diseases, mortality or different factors related with kid mortality in intensively or semi-intensively reared Black Bengal goat. The present research has been undertaken to investigate incidence of different diseases, mortality of goats and some factors affecting kid mortality in a research farm (BLRI goat farm) in order to develop herd health management system. 


\section{MATERIALS AND METHODS}

\section{Location and agro-climate}

The study was conducted at the Bangladesh Livestock Research Institute (BLRI) and Savar Government goat's farm from July 2004 to June 2005 which is located at $23^{0} 53 / \mathrm{N}, 90^{\circ} 17 / \mathrm{E}$ at an altitude of 1 meter above the sea level. Agro-ecologically belongs to the Madhupur Tract (Agro Ecological Zone 28) of Bangladesh, Red-brown Terrace strong acidic $\left(\mathrm{p}^{\mathrm{H}} 4.5-5.5\right)$ soil with very little $(<1.5 \%)$ organic matter (Brammer et al., 1988). Mean annual temperature is $25.3^{\circ} \mathrm{C}$ but can be $<15^{\circ} \mathrm{C}$ for $50-70$ days (December to February), $<20^{\circ} \mathrm{C}$ for $80-90$ days ( $24^{\text {th }}$ November to $18^{\text {th }}$ February) and $>40^{\circ} \mathrm{C}$ for $0-0.5$ day (during July). Total annual rainfall is about $2,000 \mathrm{~mm}$ during 5 months (June to October) with mean rainfall of $200 \mathrm{~mm}$. (Weather report, Department of weather).

\section{Season's description}

In case of kid mortality the seasons were described as hot and dry period (March to June), wet and hot period (July to October) and cold and dry period (November to February). But in case of adult mortality it was divided into season I (April to September) when green grasses were available in the grazing lands and plots, and season II (October to March) when green grasses were not available.

\section{Experimental animals}

An almost constant of 400 goats of different ages and sexes including 80 kids, 60 growing goats, 260 adult goats (does-160, bucks-80 and castrated male-20) were maintained throughout the study period of July 2004 to June 2005.

\section{Management of experimental animals}

Rearing systems: Goats under study were kept under intensive and semi-intensive rearing systems.

Housing: Goats were housed in a permanent wooden floor house. Jute sack and rice straw or both were used as bedding when environmental temperature low (mainly during November to February) for all age groups of goats. Kids of both sexes, growing and adult goats (bucklings, bucks and does) were kept separately. Young kids were maintained in specially designed wooden brooding pen, metallic cages and wooden floor.

Herd health care: Animals were administered with anthelmintics twice per year and were dipped in $0.5 \%$ solution of malathion or $0.02 \%$ diazinon once in every month as described by Chowdhury et al. (2002). They were vaccinated against PPR at 3-4 months of age. Control measures against contagious ecthyma, pneumonia and diarrhoea were undertaken with appropriate drugs/measures. Tetanus vaccine was not given to the farm animals.

Feeding: All the goats were reared with two categories of feeding management i.e. concentrate plus green grass (April to September) and concentrate plus urea-molasses-straw (October to March). Kids from dam with insufficient milk were maintained by foster mothers or bottle feeding. Goats were allowed to graze from 8:00 am to $4: 00 \mathrm{pm}$ with $2 \mathrm{~h}$ rest $(12: 00 \mathrm{pm}$ to $2: 00 \mathrm{pm})$ when fresh drinking water mixed with molasses and salt were supplied. Napier grasses were also supplied ad libitum at night. A concentrate mixture (45\% wheat bran, $20 \%$ khesari bran. $20 \%$ soyameal, $10 \%$ maize crushed, $2 \%$ protein concentrate, $1.5 \%$ salt, DCP $1.5 \%$ and $0.1 \%$ vitamin mineral premix) was provided twice daily in the morning and evening at the rate of 200, 250 and 100 $\mathrm{g} / \mathrm{h} / \mathrm{d}$ for bucks, does and growing kids, respectively.

Goats, which kept intensively, supplied concentrate at the same rates mentioned earlier along with green grass and water. Kids had free access to their dam for the whole day except at the grazing times when kids were allowed to the sheds where jackfruit leaves, napier grass and concentrate were also supplied. Newly born kids were allowed to stay with their mother except the initial 7 days. On an average, kids were received at least $500 \mathrm{~g}$ milk daily during the 1 st month of their life.

Breeding: Selective breeding was performed here to avoid possible in-breeding and obtain maximum genetic gain. All the records of breeding (different productive and reproductive characteristics) were kept.

Day-to-day care: Regular vigilance was performed to ensure feeding, herd health care, proper breeding, cleanliness of the farm. 
Mortality pattern of goats

\section{Disease diagnosis and data recording}

Morbidity was recorded daily on the basis of observed clinical signs and some by laboratory examinations. Suspected causes of mortality were clarified by taking history, clinical signs before death where showed, postmortem examination and in some cases by laboratory tests.

\section{Statistical analysis}

Data were analysed by using Chi-square test of fixed factor contingency table and student's $t$-test (Freed, 1992).

\section{RESULTS AND DISCUSSION}

\section{Adult mortality}

Overall adult mortality was $12.69 \%$. Higher (43.45\%) mortality was observed by Rahman et al. (1975) under farm and rural conditions. Among 33 deaths during April 2004 to March 2005, it was observed that nearly 64\% (21) died due to enterotoxaemia where only one was male goat and the rest were female (Table 1). Mortality was less in season I (April to September) (30.3\%) than season II (October to March) (69.7\%). Most of these of goats died due to suspected enterotoxaemia were apparently healthy. Along with enterotoxaemia, a small number of goats were died due to predators attack (9.1\%) and diarrhoea (6.1\%). Mannan (1989) observed the maximum mortality due to diarrhoeal diseases $(25.24 \%)$ followed by enterotoxaemia $(23.30 \%)$. However, in the present study the overall mortality was higher due to enterotoxaemia.

Table 1. Overall causes of mortality of adult goats

\begin{tabular}{|l|l|l|l|l|l|l|l|l|c|c|c|l|l|}
\hline \multirow{2}{*}{ Diseases } & \multicolumn{9}{|l|}{ Season I (April- September) } & \multicolumn{3}{l|}{ Season II October-March) } & \multicolumn{3}{l|}{ Overall } \\
\cline { 2 - 14 } & M & F & Total & $\begin{array}{c}\text { \% of total } \\
\text { mortality }\end{array}$ & M & F & Total & $\begin{array}{c}\text { \% of tal } \\
\text { mortality }\end{array}$ & M & F & Total & $\begin{array}{l}\text { \% of total } \\
\text { mortality }\end{array}$ \\
\hline Enterotoxaemia & 0 & 5 & 5 & 50 & 1 & 15 & 16 & 69.6 & 1 & 20 & 21 & 63.6 \\
\hline Diarrhoea & 0 & 0 & 0 & 0 & 0 & 2 & 2 & 8.7 & 0 & 2 & 2 & 6.1 \\
\hline Dystocia & 0 & 1 & 1 & 10 & 0 & 0 & 0 & 0 & 0 & 1 & 1 & 3.0 \\
\hline Predators & 1 & 1 & 2 & 20 & 1 & 0 & 1 & 4.3 & 2 & 1 & 3 & 9.1 \\
\hline Mechanical & 0 & 1 & 1 & 10 & 0 & 0 & 0 & 0 & 0 & 1 & 1 & 3.0 \\
\hline Others & 0 & 1 & 1 & 10 & 1 & 3 & 4 & 17.4 & 1 & 4 & 5 & 15.2 \\
\hline Total & $\mathbf{1}$ & $\mathbf{9}$ & $\mathbf{1 0}$ & $\mathbf{3 0 . 3}$ & $\mathbf{3}$ & $\mathbf{2 0}$ & $\mathbf{2 3}$ & $\mathbf{6 9 . 7}$ & $\mathbf{4}$ & $\mathbf{2 9}$ & $\mathbf{3 3}$ & \\
\hline
\end{tabular}

Most of the cases (69\%) of enterotoxaemia were occurred during periods (October-March) of restricted grazing and browsing due to lacking of green grass in the pastures, which is agreed with findings of Mannan (1989) and Ross (1981). Ingestion of excess readily fermentable carbohydrate-rich feeds predispose to reduced motility, permits more undigested starch to pass through rumen to the abomasum and intestine where it serves as a nutrient substrate for rapid proliferation of the organisms.

\section{Growing goat mortality}

It is observed from the Table 2 that among 136 kids, 30 were died $(22.1 \%)$ round the year. A higher per cent $(40.6 \%)$ were died in season II followed by III $(19.4 \%)$ and I $(14.7 \%)$. Similar results were observed by Mazumdar et al. (1980). It was also observed that highest numbers of growing kids were died due to diarrhoea (34\%) and pneumonia (28\%) where a small number due to enterotoxaemia $(10 \%)$ and bloat $(7 \%)$.

Table 2. Season-wise mortality pattern of growing kids

\begin{tabular}{|llll|}
\hline Seasons & Kids entered & No. died & Mortality rate (\%) \\
\hline I (March to June) & 68 & 10 & 14.7 \\
II (July to October) & 32 & 13 & 40.6 \\
III (November to February) & 36 & 7 & 19.4 \\
\hline Overall & $\mathbf{1 3 6}$ & $\mathbf{3 0}$ & $\mathbf{2 2 . 1}$ \\
\hline
\end{tabular}




\section{Kid mortality}

Among 359 kids born during last 15 months (January 2004 to March 2005), 104 (28.9\%). kids were died (Table 3). Comparatively higher (40\%) mortality was reported by Husain et al. (1995). About 30\% kid mortality was observed by Chowdhury et al. (2002) under semi-intensive conditions which is almost similar with the present study. Mortality without accidental causes (e.g. predators, mechanical etc.) was nearly $18 \%$.

Table 3. Mortality pattern of kid

\begin{tabular}{|l|l|l|l|}
\hline \multicolumn{2}{|l|}{ Kid died $(\mathrm{n}=359)$} \\
\hline Due to all causes & \multicolumn{2}{l|}{ Excluding predators } \\
\hline No. & $\%$ & No. & $\%$ \\
\hline 104 & 28.97 & 66 & 18.38 \\
\hline
\end{tabular}

$\mathrm{n}=$ Number of kid born

Major causes of kid mortality were infectious (63\%) followed by predators (10\%), mechanical (4\%) and congenital (1\%). Among infectious causes kids were died due to diarrhoea, pneumonia, bloat \& enterotoxaemia, ecthyma and others were found to be $30 \%, 27 \%, 23 \%, 17 \%$ and $2 \%$, respectively. Similar results were observed by Chowdhury et al. (2002) where they found $42.39 \%$ kids died due to pneumonia followed by diarrhoea (32.61\%), ecthyma (20.65\%) and bloat (4.34\%). Sriram et al. (1982) and Koul et al. (1988) observed main causes of mortality were due to pneumonia and enteritis.

Effect of birth weight of kid: Categorization of birth weight of kids were 0.5-0.8, 0.81-1.00, 1.01-1.20, 1.21-1.50, $1.51-1.80,>1.81 \mathrm{~kg}$ each having $30,81,124,72,31$ and 4 kids respectively. Kid weighing less than $0.8 \mathrm{~kg}$ birth weight had mortality $60 \%$ which decreased $\left(\chi^{2}=43.80 ; p<0.01\right)$ with the increase in kid birth weight. Similar results were found by Husain (1993), Gupta and Sengar (1985), Malik et al. (1990), Vihan et al. (1992).

Effect of birth seasons on kid mortality: Birth seasons were classified as hot and dry months (March to June), hot and wet (July to October) and cold and dry (November to February) having 103, 62 and 169 birth records in each season respectively. Hot and wet period $(41.93 \%)$ had significantly $\left(\chi^{2}=26.18 ; \mathrm{p}<0.01\right)$ higher kid mortality than cold \& dry $(12.88 \%)$ and hot and dry $(25.24 \%)$ period. Similar results were observed by Chowdhury et al. (2002), Majumder et al. (1980).

Effect of dam weight at kidding on kid mortality: Dam weight at kidding significantly affected the kid losses. Dams were categorized into weight groups as $<13 \mathrm{~kg}, 13.10-16,16.01-19,19.01-22,22.01-25,25.01-28,28.01-$ 31 and $>31 \mathrm{~kg}$ each having 7, 27, 45, 55, 67, 27, 17 and 26 observations respectively. Dam less than $13 \mathrm{~kg}$ body weight had kid mortality of more than $71 \%$ which decreased $\left(\chi^{2}=18.65 ; \mathrm{p}<0.01\right)$ exponentially with the increase in dam's weight. Similar findings were observed by Chowdhury et al. (2002).

Effect of parity: A total of $57,38,52,46,38$, and 15 birth records were recorded on $1^{\text {st }}, 2^{\text {nd }}, 3^{\text {rd }}, 4^{\text {th }}, 5^{\text {th }}$ and $6^{\text {th }}$ parity, respectively. There was no significant $\left(\chi^{2}=2.50 ; p<0.01\right)$ differences among the parities. But Chowdhury et al. (2002) found that kid mortality decreased linearly with increase in parity number.

Effect of litter size: Of 359 observations, 95, 182, 69, and 8 births were recorded for single, twine, triplet and quadruplet kidding respectively. In case of triplets the mortality had significantly $\left(\chi^{2}=3.15 ; \mathrm{p}<0.01\right)$ higher (38\%) than single (21.05\%) and twin (19.78\%). Similar results were also found by several workers (Vihan et al., 1992; Husain et al., 1995; Malik et al., 1990) but (Chowdhury et al., 2002) reported that no significance differences among single, twins and triplets kidding on mortality).

Effect of sex of kids: The mortality from birth to one month and birth to three months were 6.96 and 12.81 percent for male kids and 9.19 and 16.15 percent for female kids, respectively. Similar types of mortality rates for male kids (10.1 and 20.2 percent) were observed for all periods and higher (21.1 and 36.4 percent) for female kids by Husain et al. (1995). However, Malik et al. (1990) observed the mortality rates in male and female kids were $44.17 \%$ and 42.98\%, respectively. Honhold (2001) and Majumdar et al. (1980) found no significance differences between the sexes. 
Mortality pattern of goats

Morbidity

Overall disease incidence of goats of all age categories is shown in Table 4.

Table 4. Overall disease incidence of goats of all age categories

\begin{tabular}{|l|c|c|c|c|c|c|c|c|c|c|c|c|}
\hline \multirow{2}{*}{ Diseases } & \multicolumn{4}{|l|}{ Adult (>1 year) } & \multicolumn{3}{l|}{ Growing (3 -12 months) } & \multicolumn{3}{l|}{ Kids (0 - 3 months) } \\
\cline { 2 - 16 } & Total & M & F & $\begin{array}{c}\text { Incidence } \\
(\%)\end{array}$ & Total & M & F & $\begin{array}{c}\text { Incidence } \\
(\%)\end{array}$ & Total & M & F & $\begin{array}{c}\text { Incidence } \\
(\%)\end{array}$ \\
\hline Diarrhoea & 60 & 10 & 50 & 30.6 & 35 & 6 & 29 & 32.40 & 117 & 50 & 67 & 33.1 \\
\hline Pneumonia & 19 & 1 & 18 & 9.69 & 36 & 13 & 23 & 33.33 & 77 & 33 & 44 & 21.8 \\
\hline Ecthyma & 18 & 0 & 18 & 9.18 & 0 & 0 & 0 & - & 93 & 42 & 51 & 26.3 \\
\hline Conjunctivitis & 15 & 2 & 13 & 7.65 & 21 & 8 & 13 & 19.44 & 44 & 23 & 21 & 12.5 \\
\hline Skin disease & 3 & 0 & 3 & 1.53 & 9 & 2 & 7 & 8.33 & 15 & 7 & 8 & 4.2 \\
\hline Abortion & 3 & 0 & 3 & 1.53 & 0 & 0 & 0 & - & 0 & 0 & 0 & - \\
\hline Mastitis & 6 & 0 & 6 & 3.06 & 0 & 0 & 0 & - & 0 & 0 & 0 & - \\
\hline Metritis & 13 & 0 & 13 & 6.63 & 0 & 0 & 0 & - & 0 & 0 & 0 & - \\
\hline Bloat & 6 & 0 & 6 & 3.06 & 1 & 0 & 1 & 0.92 & 2 & 0 & 2 & 0.56 \\
\hline Abscess & 2 & 0 & 2 & 1.02 & 0 & 0 & 0 & - & 2 & 1 & 1 & 0.56 \\
\hline Foot-rot & 7 & 4 & 3 & 3.57 & 0 & 0 & 0 & - & 0 & 0 & 0 & - \\
\hline Actinobacillosis & 0 & 0 & 0 & - & 1 & 1 & 0 & 0.92 & 0 & 0 & 0 & - \\
\hline $\begin{array}{l}\text { Accidental } \\
\text { injuries }\end{array}$ & 24 & 11 & 13 & 12.24 & 0 & 0 & 0 & - & 0 & 0 & 0 & - \\
\hline Others & 20 & 6 & 14 & 10.20 & 5 & 0 & 5 & 4.62 & 3 & 0 & 3 & 0.84 \\
\hline Total & 196 & 34 & 162 & 29.83 & 108 & 30 & 78 & 16.43 & 353 & 156 & 197 & 53.72 \\
\hline
\end{tabular}

Total goats of different age and sex: $400 ; \mathrm{Kid}=80$, Growing $=60$, Adult $=260$.

Overall incidence of diarrhoea ranked the highest portion among the infectious causes in all groups of goats, similar results were also observed by Hoque (1996), where male affected only $33 \%$ cases oppose to $67 \%$ in female. Incidence of contagious ecthyma was observed in kids but none in the growing goats but observed in newly introduced adult female. Conjunctivitis was observed across all age groups of goat but the incidence was the highest in growing goat followed by kids and adults. Growing goats also had high incidence of mange (skin disease) than that of kids or adults.

Mortality rate was highest in kids $(28.97 \%)$ followed by young goats $(22 \%)$ and adult $(11.78 \%)$. Incidence of diseases were the highest during hot \& wet (July to October) followed by hot \& dry (March-June). Most of the adult mortality was due to enterotoxaemia and kid mortality due to infectious causes like diarrhoea and pneumonia. These higher mortality in semi-intensive rearing systems possibly due to increased stresses on animal, to which they responded by higher diseases incidence and mortality (Chowdhury et al., 2002). Further work is needed to reduce the adult mortality by management and preventive (vaccine) intervention. Work also need to reduce incidence of diarrhoea and pneumonia in kids and young goats.

\section{REFERENCES}

1. Acharya RM (1988). Goat breeding and meat production. Goat meat productiuon in India. Proceeding of the workshop held in Tando Jam, Pakistan.

2. Amin MR, Hussain SS and Islam ABMM (2001). Reproductive peculiarities and litter weight in different genetic groups of Black Bengal does. Asian-Australasian Journal of Animal Sciences 14 (3): 197-301.

3. Brammer H, Antonie J, Kassam AH and van Velthuizen HT (1988). Land resources appraisal of Bangladesh for agricultural development. Report- 2 (BGD/81/035). FAO of United Nations, Rome. 
4. Chowdhury SA, Bhuiyan MSA and Faruk S (2002). Rearing Black Bengal Goat under Semi-Intensive management 1. Physiological and Reproductive Performances. Asian-Australasian Journal of Animal Sciences 15 (4): 477-484.

5. Devendra C and Burns M (1983). Goat production in the tropics. Commonwealth Agricultural Bureaux, Franham House, Franham Royal, Slough SL2 3BN, UK.

6. Freed RD (1992). MSTAT Director, Crop and Soil Science Department, Michigan State University, USA.

7. Gupta UD and Sengar OPS (1985). Kid mortality as affected by birth weight, type, season and kid age in Indian goats under intensive management. Asian Journal of Dairy Research 4 (2): 71-75.

8. Herre W and Röhrs M (1973). Haustiere-Zoologisch gesehen (Compendium of basic data).

9. Honhold N (2001). Final Report on Veterinary Epidemiology. Bangladesh Livestock Research Institute, Savar, Dhaka1341, Bangladesh

10. Hoque MS (1996). MS Thesis. Clinical prevalence and findings of diseases and disorders in cattle and goats at the Central Veterinary Hospital, Dhaka. Department of Medicine, Bangladesh Agricultural University, Mymensingh, Bangladesh.

11. Husain SS (1993). A study on the productive performance and genetic potentials of Black Bengal goats. Ph. D. Dissertation. Department of Animal Breeding and Genetics. Bangladesh Agricultural University, Mymensingh.

12. Husain SS, Islam ABMM and Horst P (1995). Effect of different factors on pre-weaning survivability of Black Bengal kids. Small Ruminant Research 18: 1-5.

13. Hussain SS (1999). Sustainable genetic improvement of economic traits of Black Bengal goats through selective and cross breeding. Bangladesh Agricultural University Research Progress 10: 72-80.

14. Koul GL, Somvansha S and Biswas JC (1988). Mortality pattern in Pashmina goats. Indian Veterinary Journal 65: 847849.

15. Malik CP, Kanaujia AS, Balaine DS and Rathi SS (1990). Mortality pattern in Beetal and Black Bengal goats and their reciprocal crosses. Indian Journal of Animal Sciences 60 (2): 228-232.

16. Mannan SA (1989). MS Thesis. Study on goats mortality and their probable causes in Madhupur Upazilla of Tangail District. Department of Medicine, Bangladesh Agricultural University, Mymensingh, Bangladesh

17. Mazumdar NK, Mazumdar A and Goswami K K (1980). Studies on some factors affecting mortality and survival rates in Pashmina kids. Indian Journal of Animal Sciences 50 (3): 251-255.

18. Morand-Fehr P and Boyazoglu J (1999). Present state and future look of the small ruminant sector. Small Ruminant Research 34: 175-188.

19. Rahman A Ahmed MU and Mia AS (1975). Studies on the diseases of goats in Bangladesh. Mortality of goats under farm and rural condition. Tropical Animal Health and Production 7: 90.

20. Ross JD (1981). Herd health program for Angora goats. In: Current Veterinary Therapy, Food Animal Practice. $1^{\text {st }}$ edn., JL Howard (ed), WB Saunders Co., Philadelphia.

21. Sriram PK, Rao PR and Naidu NGR (1982). Goat mortality in Addhra Pradesh. Indian Veterinary Journal 59: 96-99.

22. Vihan VS, Kala SN and Singh VP (1992). Epidemiological investigation of neonatal kid mortality due to enteropathogenic colibacillosis. Preventive Veterinary Medicine 13 (3): 179-183. 